\title{
EFFECTS OF WATER DEFICITS ON WHOLE TREE WATER USE EFFICIENCY OF ORANGE
}

\author{
Giancarlo Roccuzzo $^{(a)}$, Francisco J. Villalobos ${ }^{(b c)}$, Luca Testi ${ }^{(b) *}$, Elías Fereres ${ }^{(b c)}$
}

a) Research Centre for Citriculture and Mediterranean Crops of Agricultural Research Council (CRA-ACM), Acireale, Italy.

b) Institute for Sustainable Agriculture - Consejo Superior de Investigaciones Científicas (IAS_CSIC), Córdoba, Spain.

c) Department of Agronomy, University of Córdoba (UCO), Córdoba, Spain.

* Corresponding author. E-Mail: lucatesti@ias.csic.es. Telephone: +34 957499295. Fax: +34 957499252. 


\section{Abstract}

To study the effects of water deficits on water use efficiency (WUE) of citrus trees, whole tree transpiration and $\mathrm{CO}_{2}$ assimilation were measured in a semi-arid environment during the summer of 2012. Young orange trees "Valencia Late", either water stressed (DI) and well-irrigated (C), were monitored in selected days using a gas exchange chamber. Tree transpiration was also measured on a continuous basis with sap flow sensors. The water restriction reduced the transpiration of the DI treatment down to $60 \%$ of the maximum potential (treatment $\mathrm{C}$ ) during the peak of water stress. The instantaneous WUE ranged between 1.7 and $79 \mathrm{~g} \mathrm{CO}_{2} \mathrm{~L}^{-1} \mathrm{H}_{2} \mathrm{O}$ and was tightly related to the vapour pressure deficit. Differences in instantaneous WUE due to water stress were insignificant. On a daily basis, WUE ranged between 4.9 (7 August) and 8.8 (7 June) g L'

${ }^{1}$ for the daytime period; and between 4.0 and $8.2 \mathrm{~g} \mathrm{~L}^{-1}$ for the $24 \mathrm{~h}$ period. As water stress was imposed on the DI treatment, a trend of increasing WUE in DI relative to C was observed, reaching, in the maximum stress period, a difference , of 13\%-15\% (daytime) and $20-22 \%$ (24h) although not statistically significant. Partial rewatering returned the WUE to similar values in both treatments. An analysis of the differences in the diurnal patterns of transpiration suggests that the increase in WUE due to water stress in citrus is achieved indirectly by shifting the overall carbon assimilation towards the morning hours of lower evaporative demand.

\section{Keywords:}

Citrus; Transpiration; CO2 assimilation; Gas-exchange chamber; Sap-flow 


\section{1. Introduction}

3 Most citrus species originated in the sub-humid, subtropical areas of south-eastern Asia

4 (Scora, 1975; Spiegel-Roy and Goldschmidt, 1996) where drought episodes are

5 infrequent but, over the centuries, the crop has adapted to the arid and semi-arid zones of

6 the world. In these areas, citrus are normally grown under irrigation and water scarcity is

7 often the norm, thus requiring that water is used as efficiently as possible. Assessing the

8 efficiency of water use in crop production has been based on quantifying the water use

9 efficiency (WUE), broadly defined in agronomy as the ratio between crop production and

10 water used (Hsiao et al., 2007). It has long been known that for a given crop and climate,

11 WUE is relatively constant, either under ample or deficient water supply (De Wit, 1958).

12 From the physiological standpoint, WUE is defined as the ratio of $\mathrm{CO}_{2}$ assimilation to

13 transpiration and is often termed transpiration efficiency (TE). For methodological

14 reasons, measurements of TE are carried out at the single leaf scale and studies

15 characterizing the TE of citrus are no exception (e.g. García-Sánchez et al., 2007;

16 Habermann et al., 2003; Nebauer et al., 2013; Ribeiro et al., 2009; Syvertsen et al., 2003;

17 Syvertsen et al., 1997). Scaling up TE measurements obtained on single leaves to

18 determine the WUE of whole trees or canopies carries a high degree of uncertainty due to

19 the variations in radiation levels and in the microclimate around trees. If whole tree

20 measurements could be performed, they should be much more meaningful for scaling up

21 to the behaviour of canopies. The use of gas-exchange chambers or canopy bags (Corelli-

22 Grappadelli and Magnanini, 1993) to measure carbon assimilation, transpiration or both

23 simultaneously in whole plants has been expanding progressively in different species: for 
24 example apple (Dragoni et al., 2005; Lakso et al., 1996), grapevine (Dragoni et al., 2006;

25 Intrigliolo et al., 2009) and olive (Pérez-Priego et al., 2010; Villalobos et al., 2012).

26 The strong theoretical and experimental evidence of the relative constancy of WUE under

27 water deficits (De Wit, 1958; Steduto et al., 2007; Tanner and Sinclair, 1983) contrasts

28 with the reports at the physiological level indicating that TE in leaves increases under

29 water deficits. Such an increase is based on an analysis of the resistance analogues to $\mathrm{CO}_{2}$

30 and $\mathrm{H}_{2} \mathrm{O}$ fluxes (Jones, 1993), and on experimental evidence at the leaf level in various

31 species (reviewed by Chaves and Oliveira, 2004). In citrus, a review of the early literature

32 (Kriedemann and Barrs, 1981) indicated that there were conflicting reports about the

33 effects of soil water deficits on TE (with some increase or decrease under water stress

34 relative to what was observed under ample supply), and concluded that further work was

35 desirable to clarify this issue.

36 Deficit irrigation is a practice that has been recommended for citrus (Ballester et al.,

37 2012; González-Altozano and Castel, 2000) but the tolerance mechanisms that operate

38 during the water deficits periods have not been uncovered. If the WUE of whole trees

39 increase under water deficits, this could be one of the mechanisms contributing to the

40 positive response that deficit irrigation elicits in several citrus species, such as orange

41 (Castel and Buj, 1990) and mandarin (Ballester et al., 2011). We conducted an

42 experiment to measure the whole-tree transpiration water use efficiency (henceforth

43 WUE) of whole young orange trees under ample and deficient water supply, to ascertain

44 the fate of tree WUE as it undergoes water stress and during recovery, at different time 45 scales 


\section{Materials and Methods}

\subsection{Site description and experimental setup}

51 The experiment was conducted at Cordoba (south-western Spain; $37.8^{\circ} \mathrm{N}, 4.8^{\circ} \mathrm{W}, 110 \mathrm{~m}$

52 altitude), at the Institute for Sustainable Agriculture of the Spanish Research Council

53 (CSIC) during summer 2012. The soil is a Typic Xerofluvent of sandy loam texture easily

54 penetrable by roots beyond $2 \mathrm{~m}$. The upper (field capacity) and lower (wilting point)

55 limits of available water are 0.23 and $0.09 \mathrm{~m}^{3} \mathrm{~m}^{-3}$, respectively.

56 The experimental plot consisted of a small orchard (nine rows with five trees per row) of

57 4-year old orange [Citrus sinensis (L.) Osbeck 'Valencia Late IVIA126'] trees, grafted on

58 'Volkamer' lemon (Citrus volkameriana Tan. and Pasq.), planted at a distance of $4 \times 4 \mathrm{~m}$.

59 The plot was fertilized with $75 \mathrm{~kg} \mathrm{ha}^{-1}$ of $\mathrm{N}, 50 \mathrm{~kg} \mathrm{ha}^{-1}$ of $\mathrm{P}$, and $50 \mathrm{~kg} \mathrm{ha}^{-1}$ of $\mathrm{K}$ in spring.

60 Trees were irrigated by the drip method, with a different combination of emitter number

61 and discharge rate to match the target irrigation treatment. Control trees had four emitters

62 per tree placed on a single drip line near the tree. Two $4 \mathrm{~L} / \mathrm{h}$ emitters were located $0.5 \mathrm{~m}$

63 away from the trunk, and two $2 \mathrm{~L} / \mathrm{h}$ emitters were placed one $\mathrm{m}$ apart from the other two,

64 on each side of the tree. The deficit treatment was irrigated with two, $2 \mathrm{~L} / \mathrm{h}$ emitters

65 placed $0.5 \mathrm{~m}$ on each side of the tree trunk, that were sided by other two $4 \mathrm{~L} / \mathrm{h}$ emitters

66 from 28 August to ensure the recover the deficit irrigated trees.. Prior to planting the

67 orchard, vertical plastic sheets of $150 \mu \mathrm{m}$ thickness were placed between the trees down

68 to $1.2 \mathrm{~m}$ depth to isolate their root systems. This allowed the use of individual trees as

69 experimental units without the need for adjacent trees acting as borders.

70 Six trees in two different water regimes were used for the experiment: 
71 - three individual trees received a control treatment (C), where irrigation fully replenished

72 the estimated crop evapotranspiration (ET). No water deficits were allowed throughout

73 the experiment. The irrigation season lasted from 16 May to 25 September.

74 - three individual trees received a deficit irrigation treatment (DI), with the same start and

75 ending dates as $\mathrm{C}$, received the following amount of irrigation:

$76-33 \%$ of the full water requirements, from 16 May until 15 July;

$77-16.5 \%$ from 16 July to 27 August;

$78-100 \%$ from 28 August to 6 September, to study the recovery from stress;

$79-33 \%$ from 8 September to 25 September (end of the season).

80 During the irrigation season the two irrigation treatments supplied $2221 \mathrm{~L}^{\text {tree }}{ }^{-1}$ (138

$81 \mathrm{~mm})$ to the Control trees and $804 \mathrm{~L} \mathrm{tree}^{-1}$ to the DI treatment $(50.3 \mathrm{~mm})$.

82 For irrigation scheduling, the full water requirements were calculated as ET-rainfall,

83 where ET was calculated using crop coefficients for citrus trees corrected for canopy size

84 and the Penman-Monteith mean monthly reference evapotranspiration or $\mathrm{ET}_{0}$ (Allen et

85 al., 1998) for Cordoba, obtained from 30-year historical data series.

\section{$87 \quad 2.2$ Gas-exchange chamber}

88 A transitory-state chamber was designed and built at IAS-CSIC for simultaneous

89 measurements of $\mathrm{CO}_{2}$ and water vapour exchange. The chamber was based on previous

90 prototypes (see Pérez-Priego et al., 2010 for description and drawing), and consisted of a

91 rectangular prism with a base of $1.2 \times 1 \mathrm{~m}$, and a height of $2 \mathrm{~m}$, giving an overall volume

92 of $2.16 \mathrm{~m}^{3}$. The walls were made with 4 sections of rigid aluminium frames and were fit

93 together with simple screws. This particular prototype has no moving windows and is 
94 placed as a cap over the tree; it fits on fixed stainless steel frames acting as a base, firmly

95 anchored in the soil around the base of each experimental tree. The bottoms of the base

96 frames are sealed with a thick polyethylene panel, thus fluxes from the soil are excluded

97 from the measurements. Leaks are avoided by placing a soft rubber gasket along the

98 junctions between the chamber and the support frame. The top and the sides of the

99 chamber are covered with clear bi-axially-oriented polyethylene terephthalate (BoPET)

100 film of $75 \mu \mathrm{m}$ thickness, stretched and fixed to the aluminium frames. The chamber

101 contains four $10 \mathrm{~W}$ fans of $15 \mathrm{~cm}$ diameter, mixing the air inside the chamber while it is

102 closed (which under normal operating conditions lasts around three minutes). A vacuum

103 pump circulates the air through the sampling circuit: the air is taken from inside the

104 chamber through many intake points, spatially distributed along the chamber and is then

105 returned to it. A sample of $1 \mathrm{~L} \mathrm{~min}^{-1}$ of this airflow is sniffed by a small pump and

106 diverted to a $\mathrm{CO}_{2} / \mathrm{H}_{2} \mathrm{O}$ infrared gas analyser (IRGA) (model LI-COR LI-840, Lincoln,

$107 \mathrm{NE}, \mathrm{USA}$ ) which measures $\mathrm{CO}_{2}$ and water vapour concentrations simultaneously at $1 \mathrm{~Hz}$

108 sampling rate; the output is recorded by a datalogger (model CR23X, Campbell

109 Scientific, Logan, UT, USA). The IRGA, datalogger and small pump were powered by

$11012 \mathrm{~V}$ batteries. The vacuum pump and the fans are powered using a small portable $\mathrm{A} / \mathrm{C}$

111 generator. An infrared thermometer (model IRR-P, Apogee, Logan, UT, USA) is

112 mounted on the centre of the chamber top, facing downwards, to measure the temperature

113 of the canopy. The sensor has a $44^{\circ}$ field of view, and can be aimed and adjusted in

114 height for optimal foliage targeting. The canopy temperature variation is checked at post-

115 processing time to ensure that the disturbance in foliage thermal conditions is negligible.

116 The air temperature and relative humidity were also measured inside the chamber with a 
117 combined probe (model HMP45AC, Vaisala, Helsinki, Finland) placed near the top of the 118 chamber into a radiation shield.

119 Two operators are needed for the opening and closing action. At the time of measuring,

120 the chamber is put on the steel frame, closed and the fans are turned on. The $\mathrm{CO}_{2}$ and

121 water vapour concentrations, measured by the IRGA, change steadily after a short lag

122 time. The concentrations of both gases are recorded at a $1 \mathrm{~Hz}$ sampling frequency. After

123 completing a measurement, the chamber is lifted up to the open position away from the

124 tree, with the fans off.

125 The IRGA was operated in the range of $0-2000 \mu \mathrm{mol} \mathrm{mol}^{-1}$ for $\mathrm{CO}_{2}$ and $0-80 \mathrm{mmol} \mathrm{mol}^{-1}$

126 for water vapour. A two-point calibration procedure was carried out in the laboratory

127 before measurement operations.

128 The fluxes were calculated by fitting a second order polynomial model to the gas

129 concentration time series, after removing the lag time (equivalent to $15 \mathrm{~s}$ in our chamber

130 arrangement) then obtaining the undisturbed gas concentration rate of change as the first

131 derivative at time zero to avoid errors due to the drift from the original gradients (Wagner

132 et al., 1997). The gas fluxes were transformed to mass basis per surface and time unit,

133 simultaneously, following Jarvis et al. (1971), and included the correction for air

134 temperature and atmospheric pressure inside the chamber (Reicosky et al., 1990).

135 The daily time course of net $\mathrm{CO}_{2}$ above-ground assimilation (A) and transpiration $\left(\mathrm{E}_{\mathrm{p}}\right)$

136 were measured on Julian days 144, 152, 159, 193, 206, 220, 242, 249 (May to September

137 2012), with repeated measurements over the whole day (starting before sunrise and

138 ending after sunset), each one lasting three minutes of chamber closure. On some days

$139(144,152$ and 193) the measurements ended before sunset due to accidental events 
140 (mainly unexpected cloudiness). The Water Use Efficiency (WUE) was calculated as

$141 \mathrm{~A} / \mathrm{E}_{\mathrm{p}}$ for the relevant time scale; WUE and transpiration efficiency (TE) are thus

142 synonyms in the context of this work. Chamber measurements began before sunrise and

143 ended after sunset, thus measurements in complete darkness and contrasting temperatures

144 were available in each measurement date. These measurements allowed to compute

145 canopy respiration $\left(R_{c}\right)$ with a simple model of the form $R_{c}=R_{0} e^{k T}$ where $R_{0}$ is the

146 measured respiration, $\mathrm{T}$ is air temperature, and $\mathrm{k}$, a constant. After being calibrated for

147 each individual tree the model was used to estimate the respiration during night-time

148 hours preceding and following the diurnal measurement curve and thus calculate A and

149 WUE for a 24 hour period.

150 The canopy conductance of the whole tree $\left(\mathrm{G}_{\mathrm{c}}\right)$ was calculated by inverting the Penman-

151 Monteith equation assuming a negligible aerodynamic resistance (imposed evaporation).

152 This assumption is reasonable for highly-coupled surfaces such as isolated trees (Raupach

153 and Finnigan, 1988), and has been successfully used in the past (Orgaz et al., 2007;

154 Villalobos et al., 2009).

155

156 2.3 Sap flow

157 Chamber measurements are necessarily discontinuous in time; to have a continuous

158 record of transpiration in both treatments tree sap flow was measured by the compensated

159 heat pulse technique. The system was installed in the summer (when the difference in

160 water status begun to be appreciable) and run until the end of the experiment. The sap

161 flow system used in this experiment was designed and manufactured at the IAS-CSIC

162 laboratory in Cordoba (Testi and Villalobos, 2009). Each sensor consists of a 4.8W 
163 stainless steel heater of $2 \mathrm{~mm}$ diameter and two four-point temperature probes, also in

164 stainless steel needle casings of the same diameter. The temperature probes were installed

16510 and $5 \mathrm{~mm}$ down- and up-stream of the heater, respectively. Each temperature probe

166 has four embedded Type E (chromel-constantan) thermocouple junctions, spaced $10 \mathrm{~mm}$

167 along the needle, sampled separately to obtain heat pulse velocities at different depths in

168 the xylem. The probes were connected to multiplexers (AM16/32, Campbell Scientific

169 Inc., Logan, UT, USA); each one allows the measurements of 8 probes. The system is

170 controlled by a datalogger (CR1000, Campbell Scientific Inc., Logan, UT, USA) that, at

171 given intervals, executes a measurement cycle consisting of: (a) measuring $\Delta \mathrm{T}$ (the

172 temperature difference between down- and upstream measurement points with respect to

173 the heater) every second during $10 \mathrm{~s}$; (b) firing a 2-s heat pulse; and (c) measuring the $\Delta \mathrm{T}$

174 every second during the following $180 \mathrm{~s}$ after each heat pulse. All the $\Delta \mathrm{T}$ measurements

175 were stored, thus allowing post-processing and assessment of data quality for each $\Delta \mathrm{T}$

176 curve following a heat pulse. The heat-pulse velocities and corresponding sap flows were

177 calculated according to Testi and Villalobos (2009), where more details about this system 178 can be found.

179 The same six trees used for the chamber measurements (three trees per treatment) were

180 equipped with one probe each. Probes were individually calibrated versus the

181 transpiration measured by the chamber, allowing the continuous recording of

182 transpiration for each tree until the end of the experiment. 
185 Volumetric soil water content was measured with a neutron probe (503 DR Hydroprobe

186 Moisture Gauge, Campbell Pacific Nuclear, Martinez, CA, USA). The probe was

187 calibrated versus gravimetric measurements of water content; for this reason soil bulk

188 density was determined in spring 2012, with soil samplings in 4 layers down to $1 \mathrm{~m}$

189 depth. Separate calibrations were performed for the upper $(0-30 \mathrm{~cm})$ and lower (below 30

$190 \mathrm{~cm}$ ) layers. Four of the six trees selected for the chamber and sap-flow measurements

191 (two trees per treatment) were also instrumented with five access tubes each, three

192 located in the wet zone and two in the dry area outside the zone wetted by the emitters.

193 Measurements were taken every 15 days in four layers $(0-15,15-30,30-60$ and $60-90 \mathrm{~cm}$

194 depth).

195 Tree leaf area was measured by counting all leaves of each tree and calculating tree leaf

196 area based on the average individual leaf area measured in a subsample of 150 leaves,

197 which were measured with an electronic planimeter (model LI-3100, LI-COR, Lincoln,

198 NE (USA). The canopy volume and ground cover was estimated by photographic image

199 analysis of the crown from four orthogonal directions.

200 Stem water potential $(\Psi)$ measurements were taken in three leaves per tree at mid-day on

201 different dates throughout the experiment to evaluate tree water status. Fully expanded

202 leaves located on branches near the main trunk were covered with aluminium foil for at

203 least 30 min before excision; afterwards, $\Psi$ was immediately measured with a pressure

204 chamber (Soil Moisture Equip., Santa Barbara, CA, USA).

205 A weather station, located $700 \mathrm{~m}$ from the experimental plot provided additional

206 meteorological data measured every $10 \mathrm{~min}$. The seasonal evolution of $\mathrm{ET}_{0}$, rainfall and

207 vapour pressure deficit (VPD) over the measurement period is shown in Fig. 1. The total 
$208 \mathrm{ET}_{0}$ for 2012 was $1322 \mathrm{~mm}$, which is considered very close to the long-term average of

209 the area; total annual rainfall was $650 \mathrm{~mm}$, value that exceeds the long term average by

210 about $15 \%$.

\section{3. Results}

215 At the start of measurements, average canopy volume was $0.82 \mathrm{~m}^{3}$ and the trees covered

$2169 \%$ of the ground. The average number of leaves per tree was 3457 (min. 2877, max.

217 3706) and the average leaf area per tree was $8.81 \mathrm{~m}^{2}\left(\min .7 .78 \mathrm{~m}^{2}\right.$, max. $\left.9.75 \mathrm{~m}^{2}\right)$. The

218 leaf area index (LAI) of the plot was $0.55\left(\mathrm{~m}^{2} \mathrm{~m}^{-2}\right)$ while the average leaf area density

219 was around $11 \mathrm{~m}^{2} \mathrm{~m}^{-3}$.

220 Even though the trees were small and the winter rainfall had filled the soil profile, the

221 irrigation treatments imposed a clear-cut influence on soil and plant water status; the

222 deficit treatment underwent mild to moderate water stress conditions - a water status

223 representative of commercial orchards managed under deficit irrigation. The soil water

224 content measured inside and outside the soil area influenced by the emitters is shown in

225 Fig. 2a and b for a $\mathrm{C}$ and a DI tree, respectively. In the $\mathrm{C}$ treatment, the soil water content

226 in the wet zone always exceeded $0.22 \mathrm{~m}^{3} \mathrm{~m}^{-3}$, being always close or above field capacity.

227 Outside the emitter influence, in the $\mathrm{C}$ treatment, the soil water declined slowly down to

$2280.17 \mathrm{~m}^{3} \mathrm{~m}^{-3}$ at the end of September (Fig. 2a), a level which corresponds to $60 \%$ of the

229 soil available water. In the DI treatment, the soil dried from the start of the differential

230 irrigation in June, reaching minimum values of $0.13 \mathrm{~m}^{3} \mathrm{~m}^{-3}$ at the end of August, and 
$2310.10 \mathrm{~m}^{3} \mathrm{~m}^{-3}$ (practically the soil lower limit) at the end of September (Fig. 2b). The

232 decline in soil water content in the wetted zone of the RDI treatment during the

233 experimental period indicated a clearly insufficient irrigation supply; only when the rate

234 of irrigation was increased in September to study the recovery the soil water content

235 increased. Following the heavy rainfall event of 26-27 September, the soil water content

236 recovered in all cases. As expected, tree water status reflected the soil water content

237 trends. The $\mathrm{C}$ treatment (Fig. 2a) maintained stem $\psi$ values between -0.4 and $-0.8 \mathrm{MPa}$,

238 with a slight overall declining trend from June to September, probably due to the gradual

239 increase in evaporative demand (see Fig. 1).

240 On the contrary, the stem $\psi$ in DI decreased quickly from values around $-0.5 \mathrm{MPa}$

241 (similar to C) at the end of June, to values close to -1.5 MPa one month later. The DI

242 stem $\psi$ was always consistently lower than that of $\mathrm{C}$ until the end of the deficit irrigation

243 period, when the increased water supply to DI caused the water status of the stressed trees

244 to approach that of C.

245 Representative observations of the diurnal courses of tree gas exchange are shown in Fig.

246 3, displaying three complete measurement days taken at; a) the beginning; b) at the

247 maximum stress; and, c) after partial relief of the water restriction. On 7 June, DOY 159

248 (Fig. 3a) the soil water content was over $0.2 \mathrm{~m}^{3} \mathrm{~m}^{-3}$ in both treatments; assimilation (A)

249 and transpiration $\left(\mathrm{E}_{\mathrm{p}}\right)$ of the two treatments were similar, although with considerable

250 fluctuations, also evident in the canopy conductance. The daily course of WUE had its

251 maximum in the early morning after sunrise, and decreased continuously until after 1600,

252 when a small rise in WUE occurs. Little or no difference in WUE can be found between

253 the two treatments, as expected; ANOVA found no significant difference $(\mathrm{p}=0.05)$ 
254 between the means at any given time of the day. Fig. 3a shows the diurnal gas exchange

255 curve taken on 7 August, when the two treatments already showed significant differences

256 in tree water status. On this date, the DI treatment had already depleted over $70 \%$ of the

257 available soil water (see Fig. 2b) and $\psi$ was below $-1 \mathrm{MPa}$. The transpiration of the $\mathrm{C}$

258 treatment exceeded that of the DI during the whole day; assimilation in C was also

259 slightly higher than in DI, especially during the early morning. Water deficits affected

260 canopy conductance which was always higher in the C treatment relative to DI. Water use

261 efficiency was very similar in both treatments, although DI had somewhat higher values,

262 especially in the morning, (930) and in the afternoon (1730); this last measurement was

263 the only one that showed statistically significant WUE between the treatments (at

$264 \mathrm{p}=0.05)$.

265 Fig. 3c depicts the diurnal course of gas exchange on 5 September, one week after the

266 irrigation rate in DI was increased to recover the DI treatment. The recovery in DI was far

267 from complete (cf. Fig. 2b) and both $A$ and $E_{p}$ are still clearly higher in $C$, as well as the

268 canopy conductance curves which are also clearly different. The two curves of WUE are

269 almost undistinguishable; no statistical differences in WUE were found at any time of the 270 day.

271 The daily integrated values of $\mathrm{A}$ and $\mathrm{E}_{\mathrm{p}}$ measured along the season are shown in Table 1,

272 with the calculated WUE for the day, both for daytime and for $24 \mathrm{~h}$. The carbon

273 assimilation peaked on 7 June, both for daytime (44.9 and $40.2 \mathrm{~g} \mathrm{CO}_{2}$ day $^{-1}$ in the $\mathrm{C}$ and

274 DI respectively) and for $24 \mathrm{~h}$ periods (41.7 and $37.9 \mathrm{~g} \mathrm{CO}_{2}$ day $^{-1}$ in the $\mathrm{C}$ and DI

275 respectively). The maximum transpiration is reached on 7 August in $\mathrm{C}\left(6.2 \mathrm{~L} \mathrm{day}^{-1}\right)$ and

276 on 24 July in DI $\left(5.3 \mathrm{~L} \mathrm{day}^{-1}\right)$. The water use efficiency of the DI (excluding incomplete 
277 days) always showed a slightly higher WUE than the C treatment except on 7 June and 5

278 September. The daily values of WUE for daytime ranged between 4.9 and $8.8 \mathrm{~g} \mathrm{CO}_{2} \mathrm{~L}^{-1}$

279 in $\mathrm{C}$ and between 5.6 and $8.6 \mathrm{~g} \mathrm{CO}_{2} \mathrm{~L}^{-1}$ in DI; for 24h periods WUE ranged between 4

280 and $8.2 \mathrm{~g} \mathrm{CO}_{2} \mathrm{~L}^{-1}$ in $\mathrm{C}$ and between 4.9 and $8.1 \mathrm{~g} \mathrm{CO}_{2} \mathrm{~L}^{-1}$ in DI. In both treatments and

281 both for daytime and for $24 \mathrm{~h}$ periods the minimum is reached on 7 August and the

282 maximum on 7 June. The measurements taken on 7 and on 29 August showed clear

283 differences: daytime WUE of DI was 15\% and 13\% (22 and 20\% for WUE in 24h) higher

284 than that of C, respectively. The difference in WUE between treatments disappears again

285 on 5 September, when the DI has already recovered for the most part from water stress

286 (Fig. 2) and was transpiring at $85 \%$ of its potential rate (see below, Fig. 4).

287 The continuous transpiration measurements (obtained from sap flow after calibration with 288 the chamber), are shown in the upper plot of Fig. 4. In the lower part of the figure, the $289 \mathrm{DI} / \mathrm{C}$ transpiration ratio is plotted over the same abscissa. Tree transpiration decreased in 290 both treatments from mid-July onwards, due to the decrease in evaporative demand; the 291 maximum was reached at the beginning of July, with a value of $9.7 \mathrm{Ltree}^{-1} \mathrm{day}^{-1}$. At that 292 time $\Psi$ of DI is beginning to drop (see Fig. 2), but the transpiration rates of $\mathrm{C}$ and DI are 293 still very similar (Fig. 4). Subsequently, at the beginning of August, the DI transpiration

294 rate dropped quite rapidly to around $60 \%$ of the potential rate due to the irrigation 295 shortage (from 33 to 16.5\%) applied at the end of July. At the end of August, the milder 296 evaporative demand and an increase in irrigation of DI (from 16\% to 100\% of crop

297 maximum ET) allowed to recover the relative transpiration rate up to 0.9. The recovery 298 proved temporary, and the transpiration of DI declined again, first steadily and then more 299 abruptly until reaching once more the value of $60 \%$ of the maximum in the second part of 
300 September. The heavy rainfalls of the last week of September (110 $\mathrm{mm}$ in 3 days) first

301 drove the transpiration of both treatments to zero due to negligible evaporative demand

302 (see Fig. 1), and then allowed the transpiration of DI to recover to $\mathrm{C}$ values in six days

303 (Fig. 4b; see also soil water content in Fig. 2b).

304 The strong inverse relation between instantaneous values of WUE and VPD in orange is

305 shown in Fig. 5a, where all the chamber measurements taken in each treatment are pooled

306 together. The same empirical model was fitted to each treatment dataset and the

307 difference between the two treatment lines is difficult to discern. Some outliers (indicated

308 by arrows) are associated to very low fluxes (both $A$ and $E_{p}$ ) which make their ratio drift

309 unpredictably; all of them are measurements taken at dawn or dusk with light close to the

310 compensation point. These outliers have been removed from the model fitting.

311 Although the difference between the two curves is barely perceivable, we computed the

312 percent gain in WUE of the DI treatment (the difference between the two curves

313 expressed in percent of the WUE of the control). While the gain at very low VPD is

314 possibly an artefact (the adopted model yields infinite WUE at VPD $=0$ ), there are hardly

315 any differences at VPD values between 1 and $2 \mathrm{kPa}$, and an increase of about $10 \%$ at

$316 \quad \mathrm{VPD}=5 \mathrm{kPa}$ (Fig. 5a).

\section{4. Discussion}

\subsection{Effects on carbon assimilation and transpiration}

321 The gas exchange measurements taken after water stress became detectable in DI showed

322 that transpiration, canopy conductance and assimilation (although in variable magnitude) 
323 were higher in $\mathrm{C}$ from dawn to dusk. Assimilation was also affected, although in variable

324 magnitude (Fig. 3b and c). The instantaneous WUE showed a clear time pattern: high in

325 the early morning then declining to a plateau in the afternoon, without fluctuations. Only

326 when the differences in water status were greatest (Fig. 2) was the instantaneous WUE

327 slightly higher in DI relative to C (Fig. 3b, 2-5\% depending on the hour but without

328 statistical significance - data not presented).

329 The average daily transpiration measured with the sap-flow probes never exceeded $10 \mathrm{~L}$

330 tree $^{-1}$ day $^{-1}$, corresponding to slightly more than $0.6 \mathrm{~mm}^{-1} \mathrm{day}^{-1}$ at orchard level. This small

331 transpiration flux is not surprising, as the trees were very young and covered only the $9 \%$

332 of the ground. As a comparison, Fig. 4 also shows the transpiration calculated trees with a

333 simple transpiration model for unstressed citrus canopies proposed by Villalobos et al.

334 (2009)., which compares well with the $C$ treatment. Consumptive transpiration in the

335 period of sap-flow measurements (11 July to 22 November) was 643 and $565 \mathrm{~L}_{\text {tree }}^{-1}$ for

336 the $\mathrm{C}$ and DI treatments respectively; the simple transpiration model predicted $669 \mathrm{~L}$ tree

$337{ }^{1}$ for the $\mathrm{C}$ treatment in the same period. The reported DI/C transpiration ratio (Fig. $4 \mathrm{~b}$ ) is

338 equivalent to the relative transpiration rate (actual over potential transpiration) of DI. The

339 relative transpiration trends of DI in September exemplify the problems of managing

340 deficit irrigation in areas of high evaporative demand. The partial recovery in

341 transpiration exhibited in September was followed by a sharp drop during the second part

342 of the month (Figure 4), even though $\mathrm{ET}_{0}$ was much less than in mid-summer (Figure 1).

343 This decline in relative transpiration in DI was caused by the low level of stored soil

344 water near the end of the irrigation season (Fig. 2), in turn generated by the deficit

345 irrigation practice. 
347 4.2 Behaviour of instantaneous WUE

348 Differences in WUE between the $\mathrm{C}$ and the DI trees were almost impossible to discern

349 (Fig. 3a, b and c). As the instantaneous WUE varies widely along the day, it is difficult,

350 due to its strong dependence on VPD, to clearly detect differences between treatments

351 given the measuring technique used (a single, portable chamber), in particular at times of

352 low VPD and when temperatures are changing rapidly. Fitting a relationship to the WUE

353 data against VPD (Fig. 5a) allows the comparison of instantaneous WUE with other

354 species or the same species in other conditions. For example in Fig. 5b the WUE curve of

355 this experiment is compared with some of the limited data available in the literature for

356 citrus trees. The fitted model with the parameters optimised for $\mathrm{C}$ fits perfectly the data of

357 orange WUE presented by Ribeiro et al. (2009) from an experiment conducted in Brazil

358 (measured range 7 to $30 \mathrm{~g} \mathrm{CO}_{2} \mathrm{~L}^{-1} \mathrm{H}_{2} \mathrm{O}$ ), and very well (especially for unshaded leaves)

359 against those of Syvertsen et al. (2003), also in orange in Florida (measured range 7.5 to

$36011.3 \mathrm{~g} \mathrm{CO}_{2} \mathrm{~L}^{-1} \mathrm{H}_{2} \mathrm{O}$ ). The agreement of our results with the two reports above is

361 remarkable, given that the WUE data were obtained at the leaf level rather than at canopy

362 level as in this experiment.

363 Olive is another evergreen that often shares the same growing areas of citrus orchards,

364 especially in the Mediterranean region. In Fig. 5a, the two lines with squares and full

365 rounded symbols represent two WUE-VPD relationships for olive obtained at different

366 spatial scales, measured respectively by Testi et al. (2008) using eddy covariance (plot

367 scale) and by Villalobos et al. (2012) using gas exchange chambers (plant scale). The

368 difference between the two curves for olive is probably the result of the evaporation from 
369 the soil, which is included when using eddy covariance and was excluded from the tree

370 chambers of Villalobos et al. (2012). Although the patterns are very similar, orange WUE

371 was always somewhat higher than that of olive, in particular in the low VPD range; this

372 could be a consequence of citrus having evolved in more humid climates than the olive,

373 where less stomatal control at low VPD (a behaviour which enhances WUE) would not

374 be detrimental, as it may be in the semi-arid environments where olive evolved.

375

$376 \quad 4.3$ Effects on WUE at different time scales

377 The two empirical models of the type $\mathrm{Y}=\mathrm{a}+\mathrm{b} \mathrm{X}^{\mathrm{c}}$, fitted to the $\mathrm{C}$ and DI datasets

378 generated very similar curves (Fig. 5a) which are not statistically different; thus, we

379 cannot conclude that instantaneous WUE in orange was affected by the level of water

380 stress tested in this experiment. Nevertheless, the relative differences between the two

381 curves plotted in a separate line (DI gain, Fig. 5a) makes it perceivable that the DI curve

382 showed always a slightly higher WUE than that fitted on C measurements, and the

383 difference was greater under high VPD (around 10\%). This behaviour is in partial

384 accordance with the output of photosynthesis-transpiration models (e.g. Dewar, 2002;

385 Tuzet et al., 2003). These models predict that the stomata closure caused by water stress

386 increases the instantaneous WUE, but to a greater extent compared to our measurements:

387 up to $30 \%$ under ranges of VPD of 4-5 KPa (Villalobos, unpublished data).

388 When the time scale changed from instantaneous to daily, the DI trees exhibited higher

389 WUE than the $\mathrm{C}$ trees (Table 1). Villalobos et al (2012) demonstrated for the olive that

390 the WUE of stressed trees was higher than that of well watered ones on longer time scales

391 (day or month), even though the instantaneous WUE was the same. The phenomenon can 
392 be explained through a different diurnal pattern of canopy conductance. The more

393 pronounced stomata closure during the afternoon that occurs in a water-stressed plant

394 shifts a greater fraction of the total daily water transpired towards the morning - a time of

395 lower evaporative demand - which enhances the overall daily WUE even with

396 instantaneous WUE similar to that of a well watered one at any time of the day. This

397 increased asymmetry in the diurnal course of transpiration has been described several

398 times in stressed plants in the past (e.g. Fereres, 1984; Olioso et al., 1996; Schulze and

399 Hall, 1982), although its impact on the WUE were not quantified. It should be highlighted

400 that every increase in the asymmetrical behaviour of stomatal conductance (with lower

401 values in the afternoon) will necessarily increase the daily WUE in semi-arid

402 environments, although at the price of decreasing the total assimilation.

403 The link between canopy conductance (or transpiration) with WUE is often subtle and it

404 is difficult to detect asymmetrical distortions between diurnal curves under different

405 water status when the magnitude of fluxes or conductances changes as well. Besides, the

406 differences in daily WUE detected in this experiment are relatively small. The diurnal

407 curves of whole-tree canopy conductance (Fig. 3), although different in magnitude, are

408 similar in shape for $\mathrm{C}$ and DI. Given that the discrete number of chamber measurements

409 prevents the appraisal of small differences in the curve shape, the continuous records of

410 sap flow could help evaluating the hypothesis of the displacement of the pattern of water

411 use in DI trees towards the morning hours. Figure 6 shows the fraction of the total $E_{p}$

412 daily flux that is transpired before 1200 (noon) in different dates, corresponding to

413 different levels of water stress in the DI. By comparing the data of Fig. 6 with Fig. 2 and

414 Table 1, as the water status of the DI declines (see also the relative transpiration rate of 
415 Fig. 4), the fraction of water transpired in the morning by DI relative to that of $\mathrm{C}$

416 increases, and the overall WUE for the day (either considering daytime or $24 \mathrm{~h}$ ) is also

417 increased. On 24 July (DOY 205) the DI treatment - even though it had a lower $\Psi \square$ than

418 C (Fig. 2) - was still transpiring at about 95\% of C (Fig. 4) and both treatments transpired

419 in the morning the same fraction of the total (38\%; Fig. 6) leading to daily WUE that

420 were practically the same (Table 1 ). On the contrary, after the $11^{\text {th }}$ of August, when water

421 stress became more noticeable in DI, the fraction of water transpired in the morning hours

422 in DI always exceeded those of C. At the beginning of September the relative

423 transpiration (Fig. 4) and its diurnal pattern matched again that of C (Fig. 6) due to the

424 partial recovery of DI. The WUE of DI at the beginning of September was again the same 425 as $\mathrm{C}$ (Table 1).

426 In conclusion, the WUE of whole orange trees ranged - on a daily basis - between 4.9 and

$4278.8 \mathrm{~g} \mathrm{CO}_{2} \mathrm{~L}^{-1} \mathrm{H}_{2} \mathrm{O}$ considering the daytime hours, and between 4.0 and $8.2 \mathrm{CO}_{2} \mathrm{~L}^{-1} \mathrm{H}_{2} \mathrm{O}$

428 over 24 hours. Water stress had a minor effect on instantaneous WUE, but showed

429 greater values than for the control trees when computed over a 24 hour period. This was

430 caused by a shift in the pattern of transpiration towards the morning hours, a behaviour

431 already documented in the olive, where the evidence is stronger than what was found in

432 this study.

433

434

435

5. Acknowledgements

436 
437 This work was financially supported by the projects CONSOLIDER-RIDECO CSD200643800067 and AGL2009-13105 of the Spanish Ministry of Science and Education, partly

439 through European Union ERDF funds. We thank Carmen Ruz (AgEng) for her estimable 440 assistance during measurements. 
443 Allen, R.G., Pereira, J.S., Raes, D., Smith, M., 1998. Crop evapotranspiration : guidelines United Nations, Rome.

Ballester, C., Castel, J., Intrigliolo, D., 2012. Response of Navel Lane Late citrus trees to regulated deficit irrigation: yield components and fruit composition. Irrig Sci, DOI 10.1007/s00271-00011-00311-00273.

Ballester, C., Castel, J., Intrigliolo, D., Castel, J., 2011. Response of Clementina de Nules citrus trees to summer deficit irrigation. Yield components and fruit composition. Agric Water Manag 98, 1027-1032.

Castel, J., Buj, A., 1990. Response of Salustiana oranges to high frequency deficit irrigation. Irrig Sci 11, 121-127.

Chaves, M.M., Oliveira, M.M., 2004. Mechanisms underlying plant resilience to water deficits: prospects for water-saving agriculture. J Exp Bot 55, 2365-2384.

Corelli-Grappadelli, L., Magnanini, E., 1993. A whole-tree system for gas-exchange studies. Hortscience 28, 41-45.

De Wit, C., 1958. Transpiration and crop yields. Verslagen van Landbouwkundige Onderzoekinge 64, 1-88.

Dewar, R.C., 2002. The Ball-Berry-Leuning and Tardieu-Davies stomatal models: synthesis and extension within a spatially aggregated picture of guard cell function. Plant, Cell and Environment 25, 1383-1398.

Dragoni, D., Lakso, A.N., Piccioni, R.M., 2005. Transpiration of apple trees in a humid climate using heat pulse sap flow gauges calibrated with whole-canopy gas exchange chambers. Agric For Meteorol 130, 85-94.

Dragoni, D., Lakso, A.N., Piccioni, R.M., Tarara, J.M., 2006. Transpiration of grapevines in the humid northeastern United States. Am J Enol Vitic 57, 460-467.

Fereres, E., 1984. Variability in Adaptive-Mechanisms to Water Deficits in Annual and Perennial Crop Plants. Bulletin De La Societe Botanique De France-Actualites Botaniques 131, 17-32. 
García-Sánchez, F., Syvertsen, J.P., Gimeno, V., Botía, P., Perez-Perez, J.G., 2007.

Responses to flooding and drought stress by two citrus rootstock seedlings with different water-use efficiency. Physiol Plant 130, 532-542.

González-Altozano, P., Castel, J., 2000. Regulated deficit irrigation in'Clementina de Nules' citrus trees. II: Vegetative growth. Journal of Horticultural Science and Biotechnology 75, 388-392.

Habermann, G., Machado, E.C., Rodrigues, J.D., Medina, C.L., 2003. Gas exchange rates at different vapor pressure deficits and water relations of 'Pera' sweet orange plants with citrus variegated chlorosis (CVC). Scientia Horticulturae 98, 233-245.

Hsiao, T.C., Steduto, P., Fereres, E., 2007. A systematic and quantitative approach to improve water use efficiency in agriculture. Irrig Sci 25, 209-231.

Intrigliolo, D., Lakso, A., Piccioni, R., 2009. Grapevine cv. 'Riesling' water use in the northeastern United States. Irrig Sci 27, 253-262.

Jarvis, P., Catsky, J., Eckardt, F., Koch, W., Koller, D., 1971. General principles of gasometric methods and the main aspects of installation design., in: Sesták, Z., Catský, J., Jarvis, P. (Eds.), Plant Photosynthetic Production. Manual of Methods. W. Junk N.V., La Hague, Netherlands, pp. 49-110.

Jones, H., 1993. Drought tolerance and water-use efficiency, in: Smith, J.A.C., H., G. (Eds.), Water deficits, plant response from cell to community. Bios Scientific Publishers, Oxford (UK).

Kriedemann, P., Barrs, H., 1981. Citrus orchards, in: Kozlowsky, T.T. (Ed.), Water deficits and plant growth. Academic Press, New York, pp. 325-417.

Lakso, A., Mattii, G., Nyrop, J., Denning, S., 1996. Influence of European Red Mite on Leaf and Whole-canopy Carbon Dioxide Exchange, Yield, Fruit Size, Quality, and Return Cropping inStarkrimson Delicious' Apple Trees. J Am Soc Hortic Sci 121, 954-958.

Nebauer, S.G., Arenas, C., Rodríguez-Gamir, J., Bordón, Y., Fortunato-Almeida, A., Monerri, C., Guardiola, J.L., Molina, R.V., 2013. Crop load does not increase the photosynthetic rate in Citrus leaves under regular cropping conditions. A study throughout the year. Scientia Horticulturae 160, 358-365. 
Olioso, A., Carlson, T.N., Brisson, N., 1996. Simulation of diurnal transpiration and photosynthesis of a water stressed soybean crop. Agric For Meteorol 81, 41-59.

Orgaz, F., Villalobos, F.J., Testi, L., Fereres, E., 2007. A model of daily mean canopy conductance for calculating transpiration of olive canopies. Funct Plant Biol 34, 178-188.

Pérez-Priego, O., Testi, L., Orgaz, F., Villalobos, F., 2010. A large closed canopy chamber for measuring $\mathrm{CO} 2$ and water vapour exchange of whole trees. Environ Exp Bot 68, 131-138.

Raupach, M.R., Finnigan, J.J., 1988. Single-Layer Models of Evaporation from Plant Canopies Are Incorrect but Useful, Whereas Multilayer Models Are Correct but Useless - Discuss. Aust J Plant Physiol 15, 705-716.

Reicosky, D., Wagner, S., Devine, O., 1990. Methods of calculating carbon dioxide exchange rates for maize and soybean using a portable field chamber. Photosynthetica 24, 22-38.

Ribeiro, R., Machado, E., Santos, M., Oliveira, R., 2009. Photosynthesis and water relations of well-watered orange plants as affected by winter and summer conditions. Photosynthetica 47, 215-222.

Schulze, E.-D., Hall, A., 1982. Stomatal responses, water loss and CO2 assimilation rates of plants in contrasting environments, Physiological plant ecology II. Springer, pp. 181-230.

Scora, R.W., 1975. On the History and Origin of Citrus. Bulletin of the Torrey Botanical Club 102, 369-375.

Spiegel-Roy, P., Goldschmidt, E.E., 1996. The biology of Citrus. Cambridge University Press.

Steduto, P., Hsiao, T.C., Fereres, E., 2007. On the conservative behavior of biomass water productivity. Irrig Sci 25, 189-207.

Syvertsen, J., Goñi, C., Otero, A., 2003. Fruit load and canopy shading affect leaf characteristics and net gas exchange of 'Spring'navel orange trees. Tree Physiol 23, 899-906. 
530 Syvertsen, J., Smith, M., Lloyd, J., Farquhar, G., 1997. Net carbon dioxide assimilation, 531 carbon isotope discrimination, growth, and water-use efficiency of Citrus trees in response to nitrogen status. J Am Soc Hortic Sci 122, 226-232.

533 Tanner, C.B., Sinclair, T.R., 1983. Efficient water use in crop production: research or re-

534 search?, in: Taylor, H.M., Jordan, W.R., Sinclair, T.R. (Eds.), Limitations to Efficient Water Use in Crop Production. American Society of Agronomy, pp. 1-27.

536 Testi, L., Orgaz, F., Villalobos, F., 2008. Carbon exchange and water use efficiency of a 537 growing, irrigated olive orchard. Environ Exp Bot 63, 168-177.

538 Testi, L., Villalobos, F.J., 2009. New approach for measuring low sap velocities in trees. $539 \quad$ Agric For Meteorol 149, 730-734.

540 Tuzet, A., Perrier, A., Leuning, R., 2003. A coupled model of stomatal conductance, 541 photosynthesis and transpiration. Plant Cell Environ 26, 1097-1116.

542 Villalobos, F.J., Perez-Priego, O., Testi, L., Morales, A., Orgaz, F., 2012. Effects of water 543 supply on carbon and water exchange of olive trees. Eur J Agron 40, 1-7.

544 Villalobos, F.J., Testi, L., Moreno-Perez, M.F., 2009. Evaporation and canopy 545 conductance of citrus orchards. Agric Water Manag 96, 565-573.

546 Wagner, S.W., Reicosky, D.C., Alessi, R.S., 1997. Regression Models for Calculating 547 Gas Fluxes Measured with a Closed Chamber. Agron J 89, 279-284. 


\section{Tables}

\section{Table 1}

Daytime totals of transpiration $\left(\mathrm{E}_{\mathrm{p}}: \mathrm{L} \mathrm{day}^{-1} \operatorname{tree}^{-1}\right)$, net above-ground $\mathrm{CO}_{2}$ assimilation (A: $\mathrm{g} \mathrm{CO}_{2}$ day $^{-1}$ tree $^{-1}$ ) and derived water use efficiency (WUE, $\mathrm{g} \mathrm{CO}_{2} \mathrm{~L}_{-1}$ ) measured with the gas exchange chamber. Values for 24 hours include the night time tree respiration, estimated by a simple model calibrated with the chamber measurements obtained before dawn and after dusk. The asterisks denote days with incomplete diurnal curves (measurements suspended before sunset due to cloudiness or equipment failure). The measured variables are presented as averages; within brackets is the standard deviation. Statistical significance at $\mathrm{p}=0.05$ is not reached in any measurement date for WUE.

\begin{tabular}{|c|c|c|c|c|c|c|c|c|c|c|c|}
\hline \multirow[b]{3}{*}{ Date } & \multirow[b]{3}{*}{ DOY } & \multicolumn{5}{|c|}{ C } & \multicolumn{5}{|c|}{ DI } \\
\hline & & \multirow{2}{*}{$\begin{array}{c}E_{p} \\
\left(L^{-1} \text { tree }^{-1}\right)\end{array}$} & \multicolumn{2}{|c|}{$\begin{array}{c}\mathrm{A} \\
\left(\mathrm{g} \mathrm{CO}_{2} \mathrm{~d}^{-1} \text { tree }^{-1}\right)\end{array}$} & \multicolumn{2}{|c|}{$\begin{array}{c}\text { WUE } \\
\left(\mathrm{g} \mathrm{CO}_{2} \mathrm{~L}^{-1}\right)\end{array}$} & \multirow[t]{2}{*}{$\begin{array}{c}E_{p} \\
\left(L d^{-1} \text { tree }^{-1}\right)\end{array}$} & \multicolumn{2}{|c|}{$\begin{array}{c}\mathrm{A} \\
\left(\mathrm{g} \mathrm{CO}_{2} \mathrm{~d}^{-1} \text { tree }^{-1}\right)\end{array}$} & \multicolumn{2}{|c|}{$\begin{array}{c}\text { WUE } \\
\left(\mathrm{g} \mathrm{CO}_{2} \mathrm{~L}^{-1}\right)\end{array}$} \\
\hline & & & daytime & $24 h$ & daytime & $24 \mathrm{~h}$ & & daytime & $24 h$ & daytime & $24 h$ \\
\hline * 23-May & 144 & $\begin{array}{c}5.0 \\
(0.1)\end{array}$ & $\begin{array}{l}35.1 \\
(0.3\end{array}$ & $\begin{array}{l}33.0 \\
(0.7)\end{array}$ & $\begin{array}{c}7.0 \\
(0.0)\end{array}$ & $\begin{array}{c}6.6 \\
(0.1)\end{array}$ & $\begin{array}{c}4.8 \\
(0.1)\end{array}$ & $\begin{array}{l}35.0 \\
(2.1)\end{array}$ & $\begin{array}{l}33.5 \\
(1.5)\end{array}$ & $\begin{array}{c}7.3 \\
(0.5)\end{array}$ & $\begin{array}{c}7.0 \\
(0.4)\end{array}$ \\
\hline * 31-May & 152 & $\begin{array}{c}6.8 \\
(1.8)\end{array}$ & $\begin{array}{l}47.8 \\
(0.7)\end{array}$ & $\begin{array}{l}44.2 \\
(0.4)\end{array}$ & $\begin{array}{c}7.1 \\
(0.3)\end{array}$ & $\begin{array}{c}6.6 \\
(0.2)\end{array}$ & $\begin{array}{c}7.0 \\
(1.3)\end{array}$ & $\begin{array}{l}50.4 \\
(6.8)\end{array}$ & $\begin{array}{l}47.9 \\
(6.1)\end{array}$ & $\begin{array}{c}7.2 \\
(0.5)\end{array}$ & $\begin{array}{c}6.9 \\
(0.6)\end{array}$ \\
\hline 7-Jun & 159 & $\begin{array}{l}5.1 \\
(0.3)\end{array}$ & $\begin{array}{l}44.9 \\
(2.6)\end{array}$ & $\begin{array}{l}41.7 \\
(2.6)\end{array}$ & $\begin{array}{c}8.8 \\
(0.1)\end{array}$ & $\begin{array}{c}8.2 \\
(0.1)\end{array}$ & $\begin{array}{c}4.7 \\
(0.4)\end{array}$ & $\begin{array}{l}40.2 \\
(2.2)\end{array}$ & $\begin{array}{l}37.9 \\
(1.4)\end{array}$ & $\begin{array}{c}8.6 \\
(0.4)\end{array}$ & $\begin{array}{c}8.1 \\
(0.4)\end{array}$ \\
\hline * 11-Jul & 193 & $\begin{array}{c}4.5 \\
(0.2)\end{array}$ & $\begin{array}{l}32.7 \\
(1.4)\end{array}$ & $\begin{array}{l}29.4 \\
(1.4)\end{array}$ & $\begin{array}{c}7.3 \\
(0.7)\end{array}$ & $\begin{array}{c}6.6 \\
(0.7)\end{array}$ & $\begin{array}{l}3.6 \\
(0.8)\end{array}$ & $\begin{array}{l}29.8 \\
(3.7)\end{array}$ & $\begin{array}{l}27.4 \\
(2.8)\end{array}$ & $\begin{array}{c}8.3 \\
(0.8)\end{array}$ & $\begin{array}{c}7.9 \\
(0.9)\end{array}$ \\
\hline 24-Jul & 206 & $\begin{array}{c}6.0 \\
(0.2)\end{array}$ & $\begin{array}{l}40.5 \\
(2.1)\end{array}$ & $\begin{array}{l}35.2 \\
(2.1)\end{array}$ & $\begin{array}{c}6.8 \\
(0.2)\end{array}$ & $\begin{array}{c}5.9 \\
(0.2)\end{array}$ & $\begin{array}{c}5.3 \\
(0.3)\end{array}$ & $\begin{array}{l}36.1 \\
(2.4)\end{array}$ & $\begin{array}{l}32.6 \\
(1.8)\end{array}$ & $\begin{array}{c}6.9 \\
(0.8)\end{array}$ & $\begin{array}{c}6.2 \\
(0.1)\end{array}$ \\
\hline 7-Aug & 220 & $\begin{array}{c}6.2 \\
(0.1)\end{array}$ & $\begin{array}{l}30.0 \\
(1.1)\end{array}$ & $\begin{array}{l}25.0 \\
(1.1)\end{array}$ & $\begin{array}{c}4.9 \\
(0.1)\end{array}$ & $\begin{array}{c}4.0 \\
(0.1)\end{array}$ & $\begin{array}{l}5.2 \\
(0.2)\end{array}$ & $\begin{array}{l}28.9 \\
(1.1)\end{array}$ & $\begin{array}{l}25.4 \\
(0.9)\end{array}$ & $\begin{array}{c}5.6 \\
(0.3)\end{array}$ & $\begin{array}{c}4.9 \\
(0.3)\end{array}$ \\
\hline 29-Aug & 242 & $\begin{array}{c}5.4 \\
(0.3)\end{array}$ & $\begin{array}{l}32.5 \\
(2.8)\end{array}$ & $\begin{array}{l}27.1 \\
(2.8)\end{array}$ & $\begin{array}{c}6.0 \\
(0.2)\end{array}$ & $\begin{array}{c}5.0 \\
(0.2)\end{array}$ & $\begin{array}{c}4.4 \\
(0.1)\end{array}$ & $\begin{array}{l}30.0 \\
(1.1)\end{array}$ & $\begin{array}{l}26.3 \\
(1.9)\end{array}$ & $\begin{array}{c}6.8 \\
(0.3)\end{array}$ & $\begin{array}{c}6.0 \\
(0.5)\end{array}$ \\
\hline 5-Sep & 249 & $\begin{array}{c}5.9 \\
(0.3)\end{array}$ & $\begin{array}{l}40.2 \\
(3.2)\end{array}$ & $\begin{array}{l}35.8 \\
(3.2)\end{array}$ & $\begin{array}{c}6.8 \\
(0.2)\end{array}$ & $\begin{array}{c}6.1 \\
(0.2)\end{array}$ & $\begin{array}{c}5.0 \\
(0.1)\end{array}$ & $\begin{array}{l}34.1 \\
(1.1)\end{array}$ & $\begin{array}{l}31.0 \\
(1.9)\end{array}$ & $\begin{array}{c}6.8 \\
(0.3)\end{array}$ & $\begin{array}{c}6.2 \\
(0.5)\end{array}$ \\
\hline
\end{tabular}




\section{List of figures}

Fig. 1 Meteorological conditions (daily values) during the experiment. Plots of reference evapotranspiration ( $\mathrm{ET}_{0}, \mathrm{~mm}$, straight line), vapour pressure deficit (VPD KPa, dotted line) and rainfall events (mm, vertical bars) for the part of the year 2012 relevant for this experiment, measured at the weather station located near the experimental plot.

Fig. 2 Seasonal evolution of the soil water content and water status of two single trees in different treatments. a: Control treatment; b: Deficit Irrigation treatment. The volumetric soil water content in the wet and dry zones (solid and dashed line respectively) is displayed separately. Also shown are the measurements of midday stem water potential $\Psi$ (MPa; white dots).

Fig. 3 Diurnal time courses of plant variables measured with chambers. Are presented: net above-ground $\mathrm{CO}_{2}$ assimilation $\left(\mathrm{A}, \mathrm{g} \mathrm{CO}_{2} \mathrm{~h}^{-1}\right)$, tree transpiration $\left(\mathrm{E}_{\mathrm{p}}, \mathrm{L} \mathrm{h}^{-1}\right)$, canopy conductance $\left(\mathrm{G}_{\mathrm{c}}, \mathrm{mmol} \mathrm{m}^{-2} \mathrm{~s}^{-1}\right)$ and water use efficiency (WUE, $\mathrm{g} \mathrm{CO}_{2} \mathrm{~L}^{-}$ ${ }^{1}$ ), measured on: a) 7 June (DOY 159); b) 7 August (DOY 220) and c) 5 September (DOY 249). All the values reported are averages of three replicates. No significant difference $(\mathrm{p}=0.05)$ between the WUE of the two treatments was found in any of these measurements, except at 1740 of 7 August.

Fig. 4. a): seasonal course of transpiration $\left(\mathrm{L} \mathrm{day}^{-1} \operatorname{tree}^{-1}\right)$ of the two treatments. The transpiration estimated by the model of Villalobos et al. (2009) for a Citrus orchard of the same ground cover is also shown. b): ratio between the water stressed (DI) and the unstressed (C) transpiration. All the values reported are 
averages of three replicates. The average standard deviation of the transpiration of a day between trees was 0.7 and $0.4 \mathrm{~L} \mathrm{day}^{-1}$ respectively for $\mathrm{C}$ and DI.

Fig. 5. Relationship between WUE and instantaneous Vapour Pressure Deficit a): experimental data of well irrigated (C, circles) and water stressed (DI, crosses) treatments. The curves represent the empirical models fitted to the data: $\mathrm{C}$ (solid line, $\mathrm{n}=231$ ), DI (dashed line, $\mathrm{n}=236$ ). The fitted curve for both treatment data pooled together (not shown in the picture) has the equation $2.65+20.1 \mathrm{VPD}^{-1.47}$. The relative difference between the two models (DI gain) is plotted as dotted line. Also shown are the empirical fits of WUE obtained in olive by Testi et al. (2008) by eddy covariance and by Villalobos et al. (2012) by chambers. b): WUE measurements reported in unshaded leaves by Syvertsen (2003) and Ribeiro (2009) are plotted over the curve fitted to the Control in this experiment.

Fig. 6. Fraction of the total water transpired before noon by the two treatments (averages) in days with different water status of the DI. The relative transpiration for each day (Ep DI / Ep C) is also reported. 

Figures

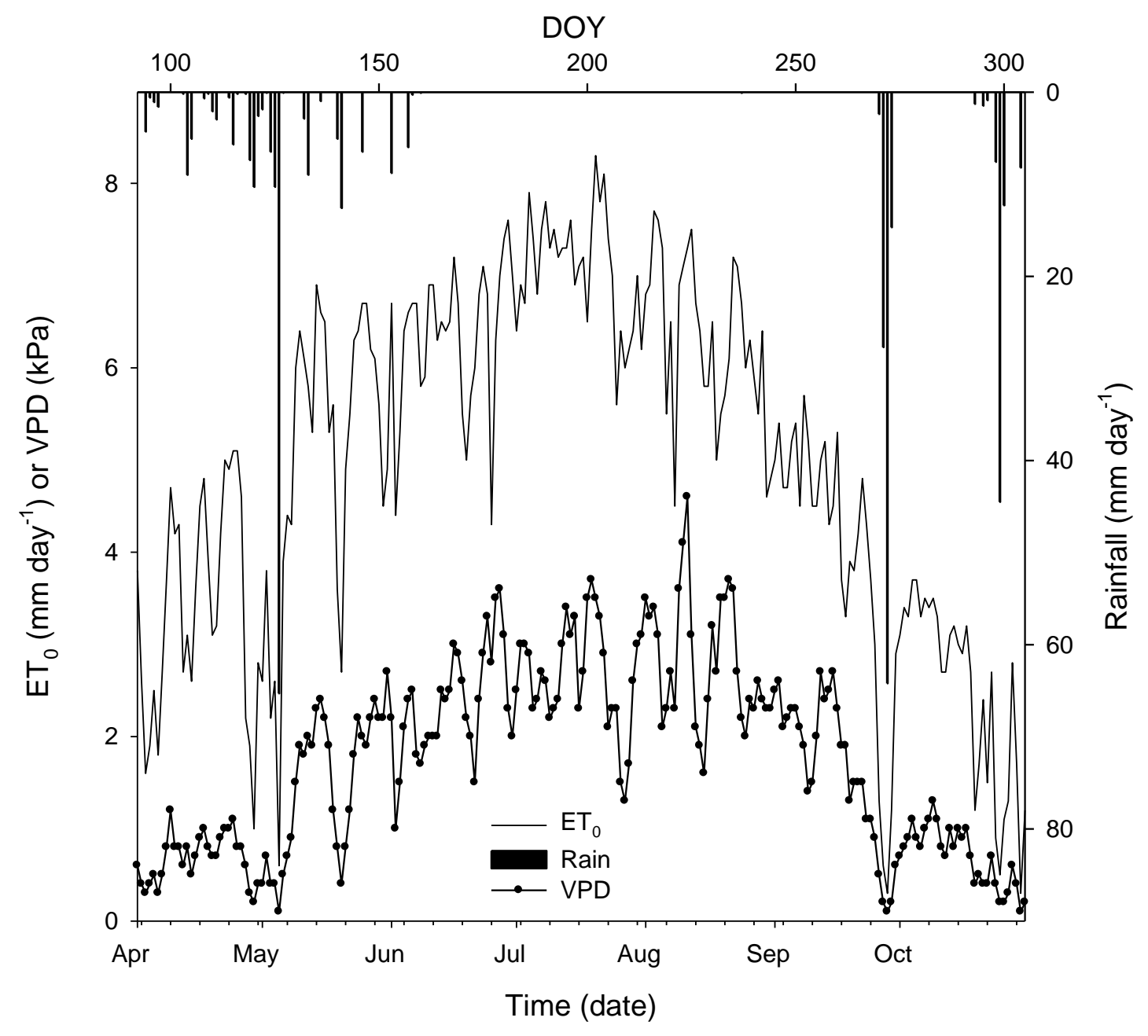

Fig. 1 


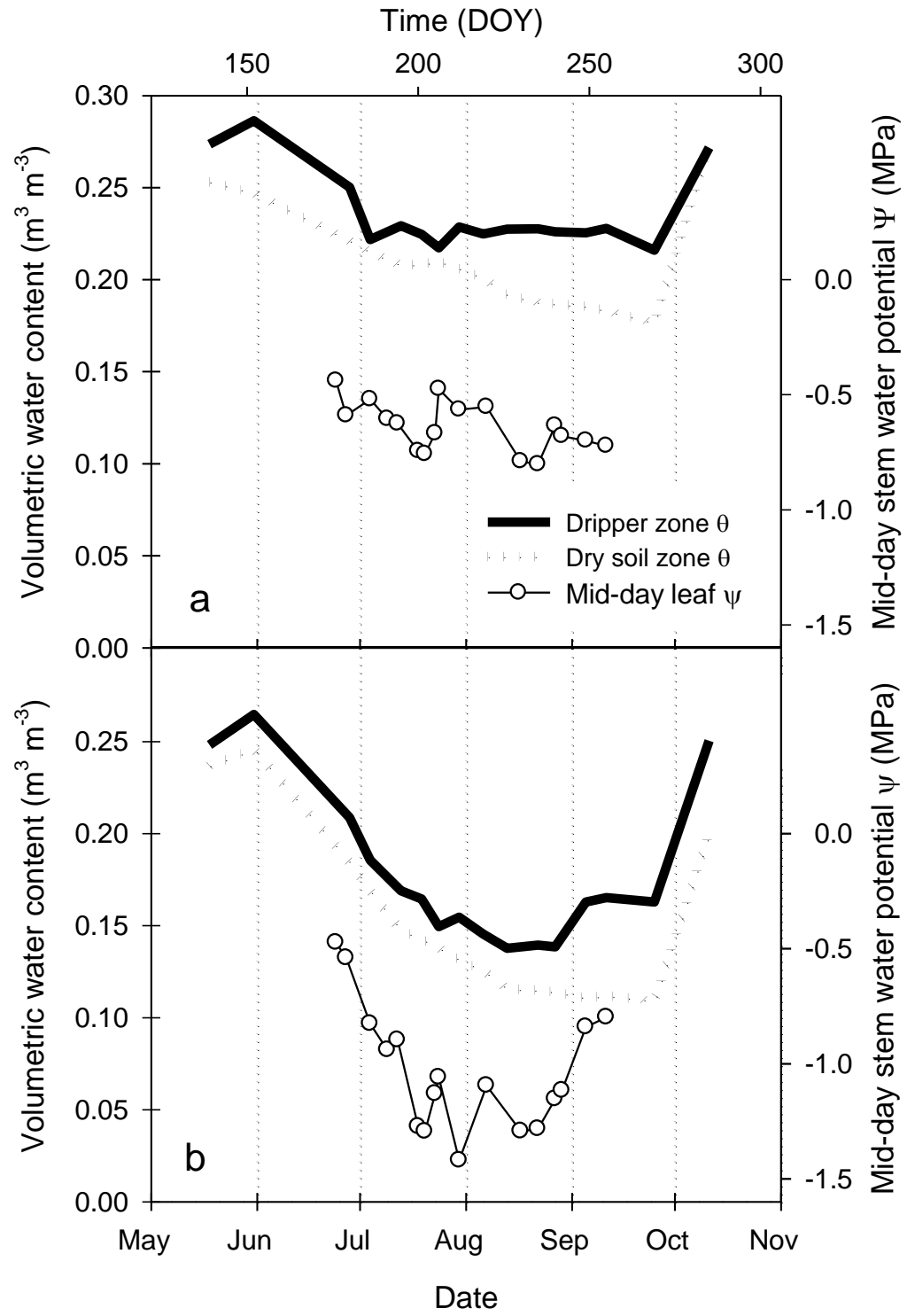

Fig. 2 
a
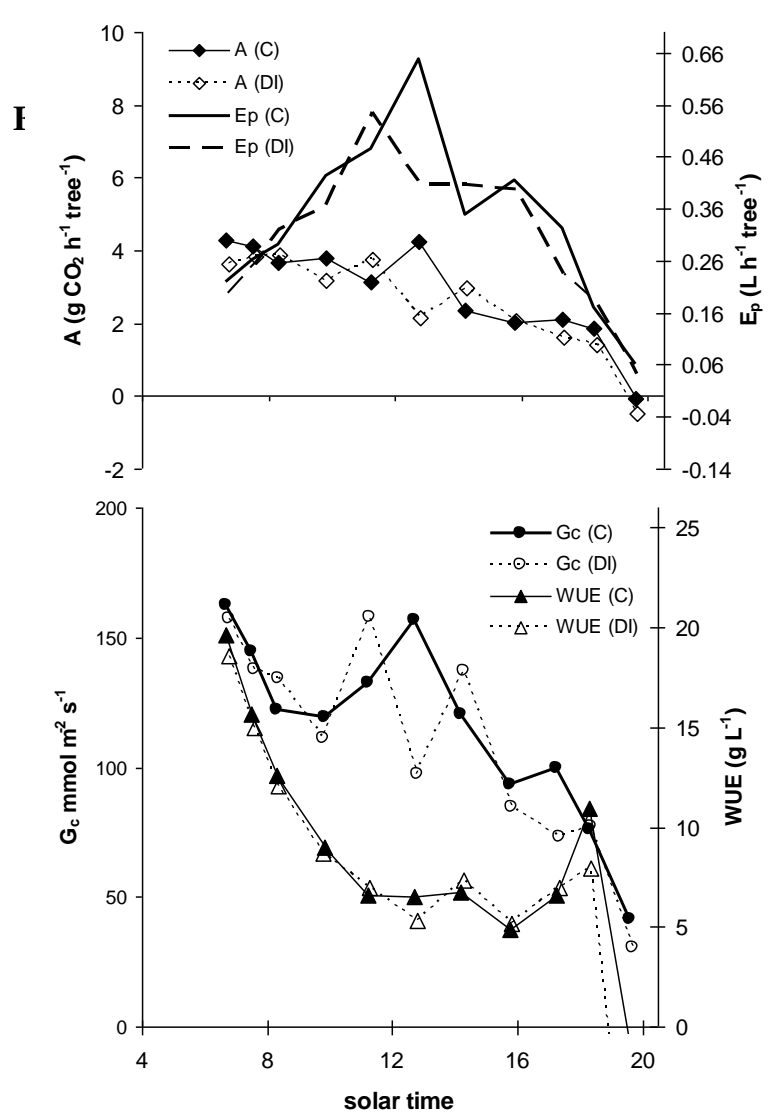

b
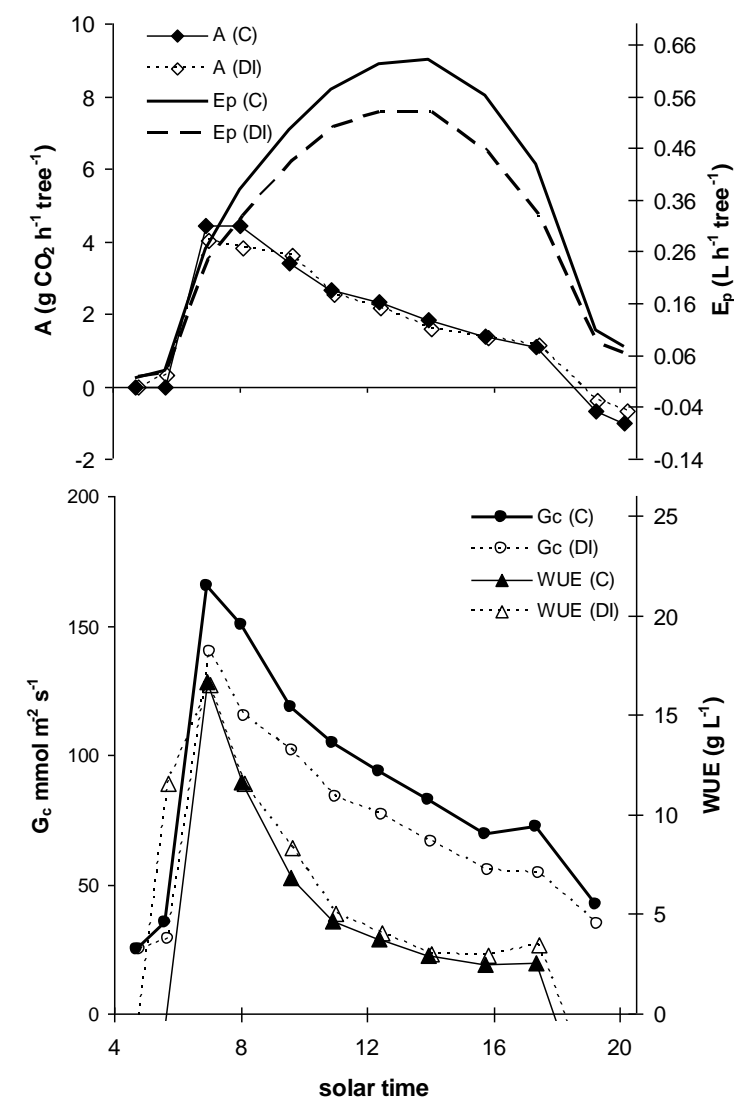

C 5 September (DOY 249)

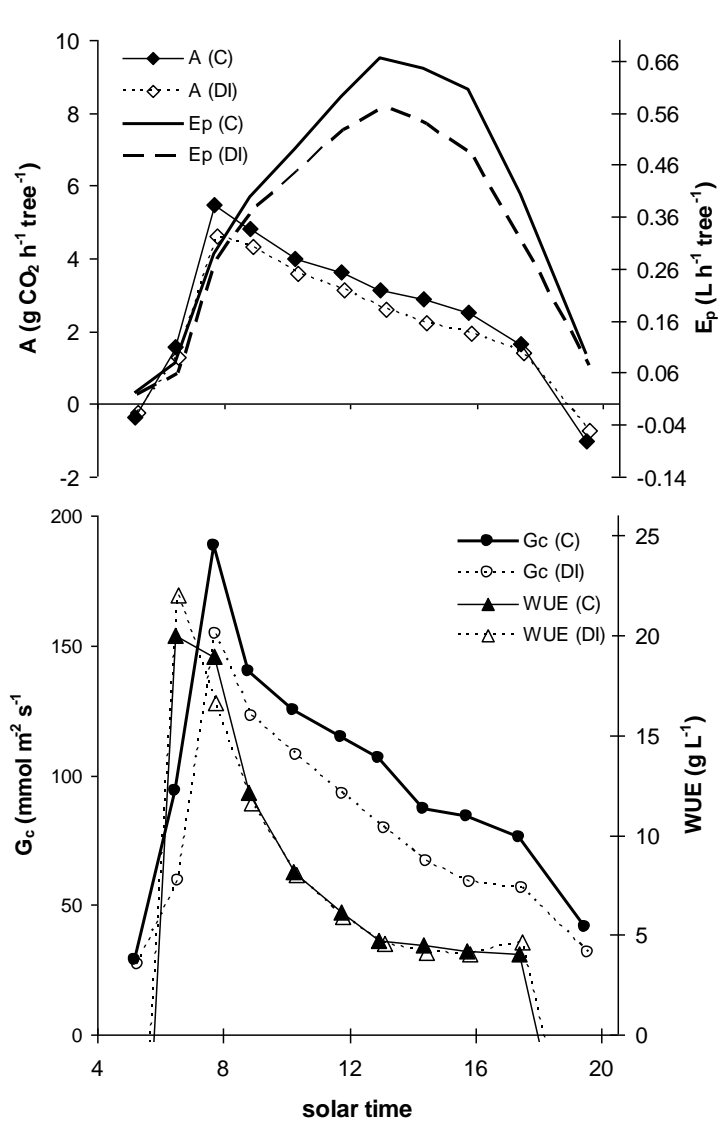




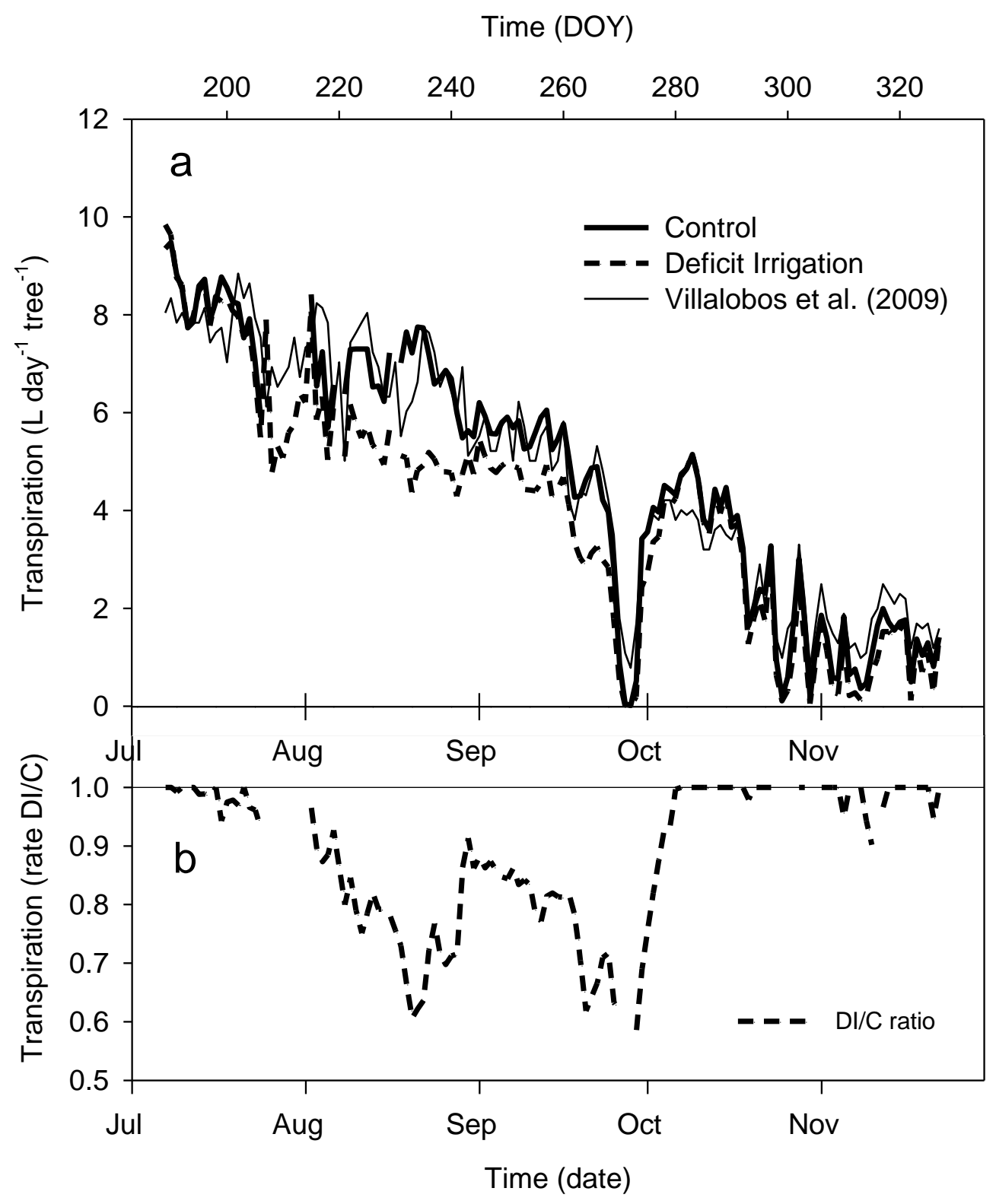

Fig. 4 


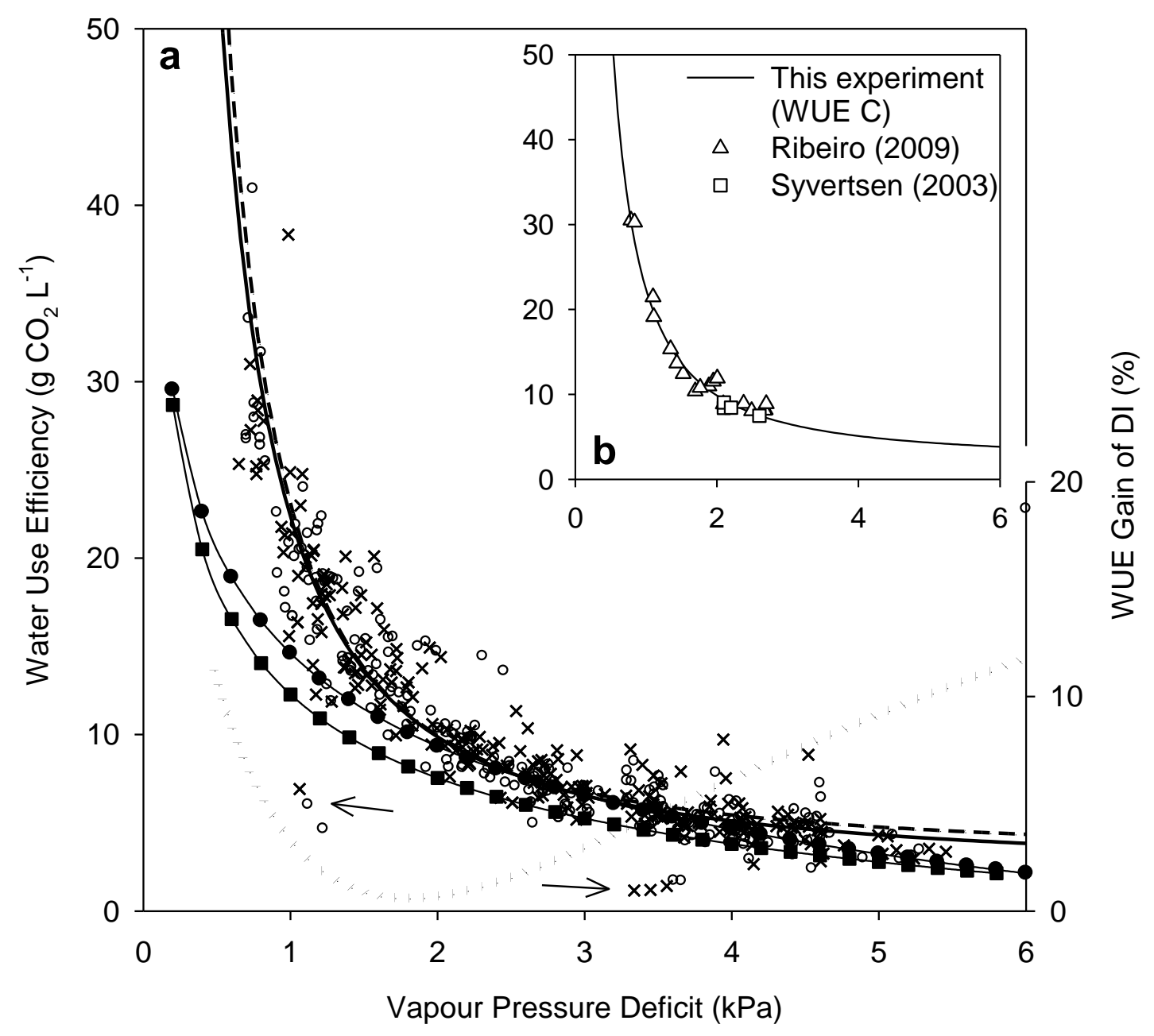

- Control (C)

$\times \quad$ Deficit Irrigation (DI)

WUE $(C)=2.16+20.21$ VPD $^{-1.39}$

-- WUE $(\mathrm{DI})=3.10+20.03 \mathrm{VPD}^{-1.55}$

,, WUE Gain of DI

$\longrightarrow$ Olive (well-watered, Testi et al., 2008)

—- Olive (well-watered, Villalobos et al., 2012) 
Fig. 5 


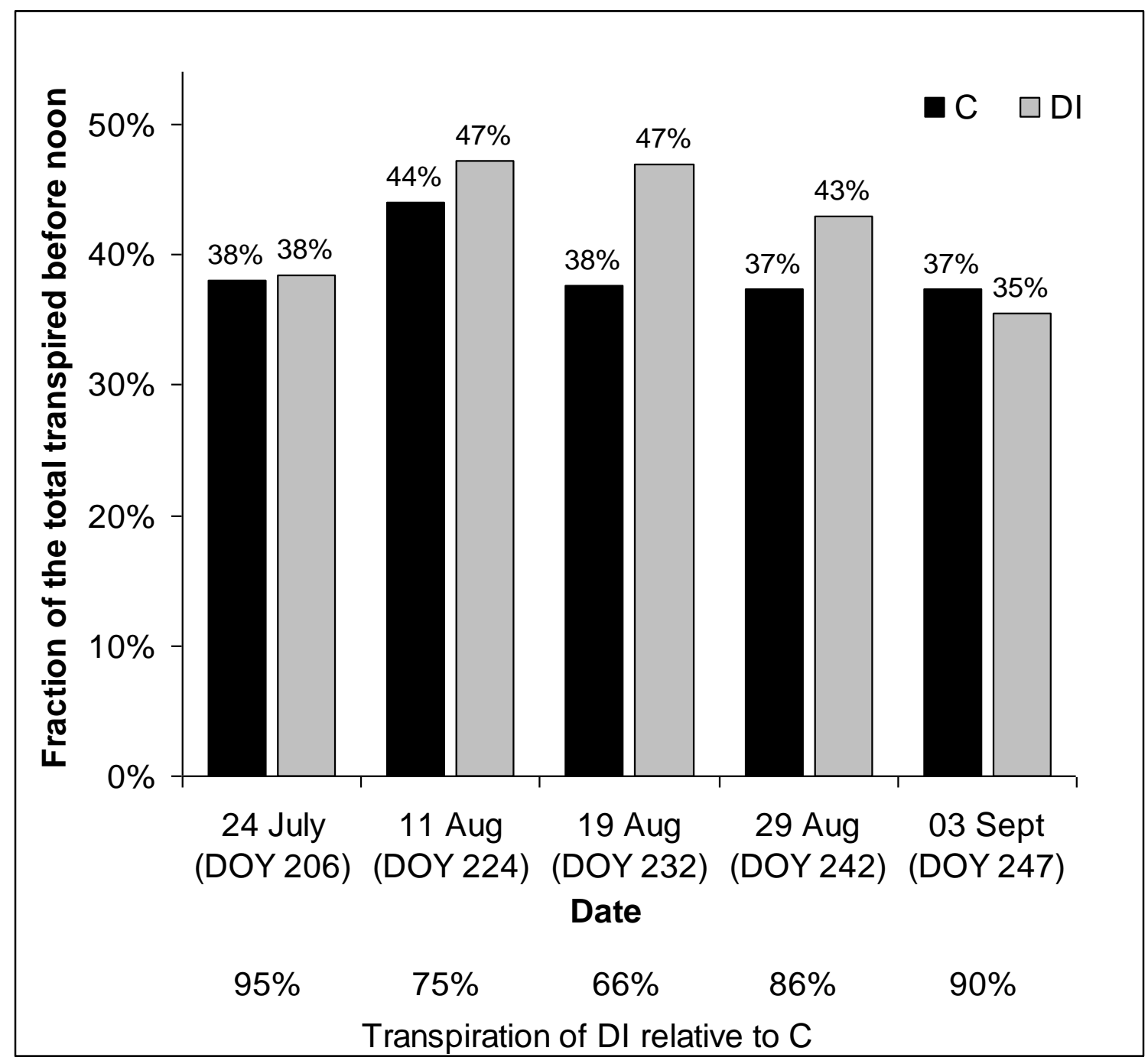

Fig. 6 